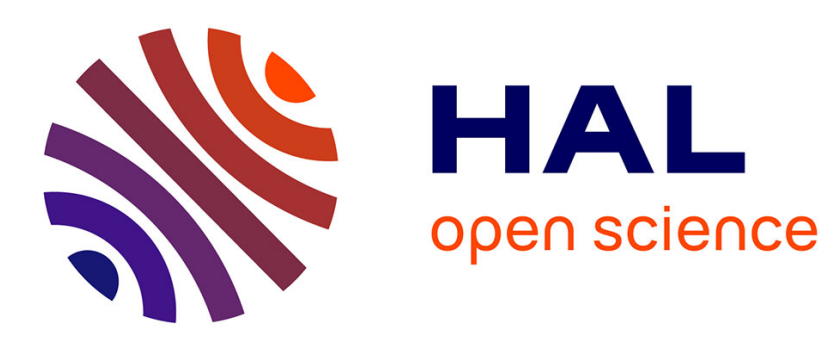

\title{
Intercomparison of Integrated Water Vapor Estimates from Multisensors in the Amazonian Region
}

Luiz F Sapucci, Luiz a T Machado, João F G Monico, Artemio Plana-Fattori

\section{To cite this version:}

Luiz F Sapucci, Luiz a T Machado, João F G Monico, Artemio Plana-Fattori. Intercomparison of Integrated Water Vapor Estimates from Multisensors in the Amazonian Region. Journal of Atmospheric and Oceanic Technology, 2007, 24 (11), pp.1880-1894. 10.1175/JTECH2090.1 . hal-03140387

\section{HAL Id: hal-03140387 \\ https://hal.science/hal-03140387}

Submitted on 12 Feb 2021

HAL is a multi-disciplinary open access archive for the deposit and dissemination of scientific research documents, whether they are published or not. The documents may come from teaching and research institutions in France or abroad, or from public or private research centers.
L'archive ouverte pluridisciplinaire HAL, est destinée au dépôt et à la diffusion de documents scientifiques de niveau recherche, publiés ou non, émanant des établissements d'enseignement et de recherche français ou étrangers, des laboratoires publics ou privés. 


\title{
Intercomparison of Integrated Water Vapor Estimates from Multisensors in the Amazonian Region
}

\author{
Luiz F. SAPUCCI AND Luiz A. T. MAchado \\ Centro de Previsão de Tempo e Estudos Climáticos, Instituto Nacional de Pesquisas Espaciais, Cachoeira Paulista, São Paulo, Brazil \\ Jõ̃o F. G. MONICO \\ Departamento de Cartografia da Faculdade de Ciências e Tecnologia da Universidade Estadual Paulista, Presidente Prudente, \\ São Paulo, Brazil \\ Artemio Plana-Fattori \\ Centre d'Etude des Environnements Terrestre et Planetaires, Institut Pierre Simon Laplace, Velizy-Villacoublay, France
}

(Manuscript received 26 July 2006, in final form 23 February 2007)

\begin{abstract}
Water vapor is an atmospheric component of major interest in atmospheric science because it affects the energy budget and plays a key role in several atmospheric processes. The Amazonian region is one of the most humid on the planet, and land use change is able to affect the hydrologic cycle in several areas and consequently to generate severe modifications in the global climate. Within this context, accessing the error associated with atmospheric humidity measurement and the validation of the integrated water vapor (IWV) quantification from different techniques is very important in this region. Using data collected during the Radiation, Cloud, and Climate Interactions in Amazonia during the Dry-to-Wet Transition Season (RACCI/DRY-TO-WET), an experiment carried out in southwestern Amazonia in 2002, this paper presents quality analysis of IWV measurements from RS80 radiosondes, a suite of GPS receivers, an Aerosol Robotic Network (AERONET) solar radiometer, and humidity sounding from the Humidity Sounder for Brazil (HSB) aboard the Aqua satellite. When compared to RS80 IWV values, the root-mean-square (RMS) from the AERONET and GPS results are of the order of 2.7 and $3.8 \mathrm{~kg} \mathrm{~m}^{-2}$, respectively. The difference generated between IWV from the GPS receiver and RS80 during the daytime was larger than that of the nighttime period because of the combination of the influence of high ionospheric activity during the RACCI experiment and a daytime drier bias from the RS80.
\end{abstract}

\section{Introduction}

Atmospheric water vapor plays a crucial role in the atmospheric processes, and its distribution is associated with cloud concentration and rainfall. Water vapor advection and the release of latent heat influence the vertical stability and the structure and evolution of atmospheric storm systems. This atmospheric component has the greatest temporal and spatial variability, and is capable of fluctuating by several orders of magnitude in both location and height in a short period of time.

Corresponding author address: Luiz Sapucci, Centro de Previsão de Tempo e Estudos Climáticos, Instituto Nacional de Pesquisas Espaciais, Rodovia Presidente, Dutra, km 40, CEP, 12630000, Cachoeira Paulista, São Paulo, Brazil.

E-mail: 1sapucci@cptec.inpe.br
The Amazonian region is distinguished by large space-time variability in the humidity fields caused by the intense convective process, which is frequent in this region, allied to great humidity potential generated by high temperatures. This region is one of the most humid on the planet, where the integrated water vapor (IWV) average is of the order of $50 \mathrm{~kg} \mathrm{~m}^{-2}$ (Sapucci et al. 2004). The impact of land use change on the climatological, ecological, biogeochemical, and hydrological functioning of Amazonia and the interactions between Amazonia and the earth's system are currently being investigated. Some researchers suspect that increased clearing of forests for agricultural use will affect the hydrologic cycle (IWV, in particular) and, consequently, the rainfall regime in several areas, resulting in severe changes to the global climate (Nobre et al. 1991;

DOI: 10.1175/JTECH2090.1

(C) 2007 American Meteorological Society 
Manzi and Planton 1996). In addition, several papers have shown that the assimilation of IWV measurements into numeric weather prediction recovers the vertical structure of water vapor and improves short-range precipitation forecasting (Kuo et al. 1993, 1996; Ledvina and Pfaendtner 1995; Hou et al. 2000). The preliminary results obtained in an impact study of the inclusion of IWV values from satellite sensors in the Centro de Previsão de Tempo e Estudos Climáticos (CPTEC) data assimilation system has shown that the benefits are more significant over the regions where the density of conventional information is lower, such as in the Amazonian region (Sapucci et al. 2006). In this context, accessing the errors associated with atmospheric humidity measurements from indirect techniques, such as radiometers, ground-based global positioning system (GPS) receivers, and humidity sounding satellites is very important in this region.

Several comparison and intercomparison experiments of humidity measurement techniques have been carried out in other regions to describe and improve the accuracy of atmospheric water vapor measurements. Radiosondes have been intercompared in several experiments and very important results that have improved this technique have been obtained. Turner et al. (2003), Miller et al. (1999), Guichard et al. (2000), Miloshevich et al. (2001), and Wang et al. (2002) have suggested the usage of an altitude-independent scale factor and corrections in the humidity measurement from the Vaisala RS80H radiosonde. Because nowadays the RS80 is the most commonly used radiosonde, its performance was evaluated in operational usage, comparing it against a more sophisticated humidity sensor (Paukkunen et al. 2001; Wang et al. 2001; Fujiwara et al. 2003). Several papers have shown the GPS receiver performance in the quantification of atmospheric water vapor by comparing their results with those obtained from radiosondes and microwave radiometers (Duan et al. 1996; Ware et al. 1997; Rocken et al. 1997; Emardson et al. 2000; Tsuda et al. 1998; Reigber et al. 2002; Marel 2001, and others). Radiosondes and GPS receivers were used in the validation of the other humidity measurement techniques, like solar radiometers (Ingold et al. 2000 ) and humidity sounding satellites (Wolfe and Gutman 2000), and were also used in experiments with intensive water vapor observation periods (Revercomb et al. 2003) to describe and improve the accuracy of water vapor measurements.

An experiment with the intensive collection of physical and chemical information from the atmosphere was carried out in 2002, during the transition from the dry to the wet season. This experiment was called the Radiation, Cloud, and Climate Interactions in Amazonia dur- ing the Dry-to-Wet Transition Season [RACCI/DRYTO-WET; Silva Dias et al. (2002)] and was carried out in several cities in the state of Rondônia, Brazil, where the clearing of forests for agriculture and cattle raising is quite advanced. The main aim of RACCI is to understand the physical processes that control the transition season in southwestern Amazonia and the regional effects of aerosols generated from biomass burning, which is quite a common practice in this area at the end of the dry season. The interaction between these aerosols, water vapor, and liquid water is an important subject in regards to the RACCI experiment. Consequently, high-resolution IWV estimates can contribute to the understanding of the physics process involved in anthropogenic changes and the climate. IWV quantification by radiosondes, GPS receivers, solar radiometers, and humidity sounding satellites were used to investigate the interaction between aerosols from biomass burning and the physics process involved in the atmospheric water vapor cycle.

This study describes the relative quality of IWV measurements from radiosondes, GPS receivers, and a solar radiometer and sounding satellite in the Amazonia region. This information can be important in assessing the relative uncertainty of the radiosondes' humidity profile, which is the main observation system used to achieve the aims of RACCI. The instrument details and collected data are described in section 2. In section 3 the data processing from different techniques for water vapor atmospheric quantification is presented. The results obtained from the comparison of IWV from radiosondes, a solar radiometer, a humidity satellite sounding, and the GPS receivers are presented in section 4 . In section 5 the main results are summarized and conclusions are presented.

\section{Instruments used and collected data for IWV quantification in the RACCI experiment}

The RACCI experiment was composed of three sites with intensive collection of atmospheric information located in Rondônia State into the Amazonian region. The sites involved in the IWV experiment are called Abracos-Fazenda Nossa Senhora (ABRA), Guajará Mirim (GJMI), and Porto Velho (PTVE) stations. Figure 1 shows the geographic localization of the RACCI experiment stations. The period of the experiment was from 12 September to 3 November 2002. The instruments used in the IWV comparison experiment are described below.

\section{a. Radiosonde}

All of the used radiosondes were Vaisala, model RS80-15G. The launch times were 0000, 1200, and 1800 

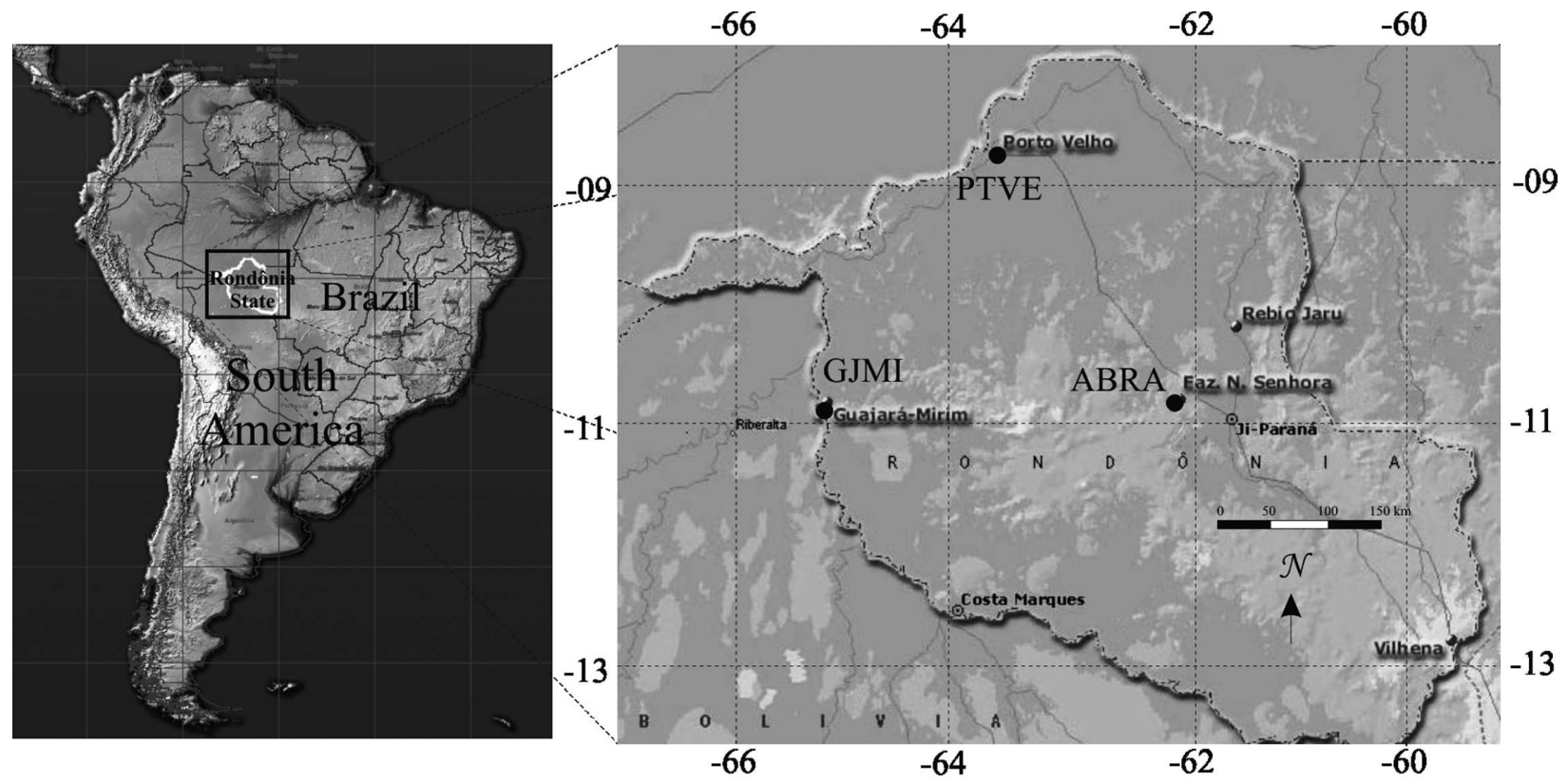

FIG. 1. Geographic localization of the RACCI experiment stations.

UTC at the ABRA station and 0000 and 1200 UTC at the GJMI and PTVE stations. In the first and last 15 days of the campaign launching was intensified, with extra launches at 0600, 1500, and 2100 UTC at the ABRA station and 0600 and 1800 UTC at the GJMI and PTVE stations. A total of 214 radiosondes were released in ABRA, 143 in GJMI, and 110 in PTVE during the RACCI experiment.

\section{b. Solar radiometer}

In the ABRA station, there is a Cimel CE-318 sunsky photometer operating since 1999 in the scope of the worldwide Aerosol Robotic Network (AERONET). The analysis of solar transmission measurements near the water vapor absorption band near $940 \mathrm{~nm}$ provides IWV estimates many times a day between sunrise and sunset (Holben et al. 1998).

\section{c. Humidity satellite sounding}

The humidity from satellite sounding used here was obtained from the Aqua satellite. The IWV retrieved from the Aqua satellite were obtained by the Humidity Sounder for Brazil (HSB) sensor (Lambrigtsen and Calheiros 2003).

\section{d. GPS receiver}

GPS data used to derive the IWV value during the RACCI experiment were collected using one Ashtech receiver, with the ZXII model installed in the ABRA station (Marine C antenna), and two Topcon brand Legacy-H models in the GJMI and PTVE stations (LegAnt E antenna). These antennas are a dualfrequency type. In the ABRA station the GPS antenna was installed in a metal base, and in the GJMI station a metal stem that was fixed on a building was used. In the PTVE station it was installed in a tripod on the control tower at the Porto Velho-Belmonte Airport. This data collection was carried out using a 24-h session in GJMI and PTVE and a 22.3-h session in ABRA, with a 30-s interval and a cutoff elevation angle of $10^{\circ}$. The data collection period for each measurement type in each site was not equal because of operational constraints related to the installation and uninstallation process for the devices involved. Table 1 summarizes the collection period for each technique together with the geographic localization of the RACCI stations.

\section{Data processing}

The IWV from radiosondes were obtained applying the following expression:

$$
\mathrm{IWV}=\int_{h_{0}}^{h} \rho_{w}(z) d z,
$$

with $\rho_{w}(z)$ the water vapor density at height $z$ from $h_{0}$ to the top of the atmosphere $h ; \rho_{w}$ was calculated using radiosonde dewpoint temperature and pressure measured along the atmospheric vertical column. The mini- 
TABLE 1. Sites and periods of data collection under consideration in this study.

\begin{tabular}{|c|c|c|c|c|c|c|c|}
\hline $\begin{array}{l}\text { RACCI } \\
\text { station }\end{array}$ & Lat & Lon & $\begin{array}{l}\text { Collection } \\
\text { period }\end{array}$ & $\begin{array}{l}\text { Radiosonde } \\
\text { launching }\end{array}$ & GPS receiver & HSB sensor & AERONET radiometer \\
\hline \multirow[t]{2}{*}{ ABRA } & $10^{\circ} 45^{\prime} \mathrm{S}$ & $62^{\circ} 21^{\prime} \mathrm{W}$ & Begin & $12 \mathrm{Sep}$ & $21 \mathrm{Sep}$ & 12 Sep & $1 \mathrm{Sep}$ \\
\hline & & & End & 3 Nov & 3 Nov & 3 Nov & 15 Nov \\
\hline \multirow[t]{2}{*}{ PTVE } & $08^{\circ} 42^{\prime} \mathrm{S}$ & $63^{\circ} 53^{\prime} \mathrm{W}$ & Begin & 20 Sep & 18 Sep & $12 \mathrm{Sep}$ & $\ldots$ \\
\hline & & & End & 29 Oct & 29 Oct & 3 Nov & $\ldots$ \\
\hline \multirow[t]{2}{*}{ GJMI } & $10^{\circ} 45^{\prime} \mathrm{S}$ & $65^{\circ} 18^{\prime} \mathrm{W}$ & Begin & $15 \mathrm{Sep}$ & $15 \mathrm{Sep}$ & $12 \mathrm{Sep}$ & $\cdots$ \\
\hline & & & End & $28 \mathrm{Oct}$ & 28 Oct & $3 \mathrm{Nov}$ & $\ldots$ \\
\hline
\end{tabular}

mum height of the vertical column considered in this process was $8 \mathrm{~km}$. A total of 14,6 , and 8 radiosondes in the ABRA, GJMI, and PTVE stations, respectively, were discarded from the analysis because they either did not reach this height or presented some other type of problem during launching. Concerning the radiosonde data, rigorous quality control was carried out in order to avoid the inclusion of possible outliers in the analysis.

$$
\mathrm{IWV}=\frac{1}{m}\left\langle\frac{1}{a}\left\{\ln \frac{V_{0}(\lambda) d^{-2}}{V(\lambda)}-m\left[\tau_{R}(\lambda)+\tau_{a}(\lambda)+\tau_{3}(\lambda)\right]\right\}\right\rangle^{1 / b},
$$

where $m$ is the relative optical air mass, which is a function of the solar zenith angle; $V_{0}(\lambda)$ is the instrument calibration constant; $d$ is the earth-sun distance; and $\tau_{R}, \tau_{3}$, and $\tau_{a}$ are Raleigh scattering by air molecules, absorption owing to $\mathrm{O}_{3}$, and attenuation caused by aerosol particles, respectively. Constants $a$ and $b$ were obtained by modeling solar transmission with the help of a radiative transfer model; in the case of the former AERONET level 1.5 results, the LOWTRAN-7 code was considered (Schmid et al. 2001). Such a procedure is meaningfully dependent on the representation of water vapor absorption that is adopted to provide the dataset of benchmark results from which $a$ and $b$ coefficients are derived. However, previous studies have shown that the atmospheric transmittance at 940 $\mathrm{nm}$ (and, hence, estimates of water vapor content from solar transmission measurements at this band) can be substantially affected by changes in line parameters (Schmid et al. 2001), in the continuum model (Vogelmann et al. 1998), and even in the radiative transfer line-by-line model used for obtaining benchmark results (Plana-Fattori et al. 2004). The production of AERONET level 2.0 results takes into account a recently updated algorithm for estimating the water vapor content. Such an update involves the application of a more reliable representation of the water vapor line and continuum absorption regimes near
Solar transmission measurements from the Cimel instrument (AERONET) are typically performed every 15 min between sunrise and sunset, at selected wavelengths centered between 340 and $1020 \mathrm{~nm}$. Holben et al. (1998) have discussed the operation and philosophy of the monitoring system, as well as the accuracy of the measuring radiometers. The IWV value is obtained from the Cimel output voltage $V(\lambda)$ at wavelength $\lambda$ applying following expression (Schmid et al. 2001):

$940 \mathrm{~nm}$ into a more reliable radiative transfer model (A. Smirnov 2006, personal communication). A new quality control was used in the production of the level 2.0 AERONET. Therefore, the files containing level 1.5 and 2.0 products for the ABRA site show some differences in the time series being treated in this investigation.

The HSB was designed to detect radiances in the bands of 150 and $183 \mathrm{GHz}$, with smaller susceptibility to radiofrequency interference than the Advanced Microwave Sounding Unit (AMSU)-B sensor (Rosenkranz 2001). The HSB is composed of three channels around the absorption band of the water vapor $(183.31 \mathrm{GHz} \pm$ $1, \pm 3$, and $\pm 7 \mathrm{GHz}$ ), as well as another in the atmosphere window around $150 \mathrm{GHz}$. The HSB horizontal resolution is about $14 \mathrm{~km}$ in the nadir direction. IWV were retrieved only when the cloud cover was lower than $30 \%$. Considering this constraint, the number of computed IWV was only 24 , considering all stations (5 in ABRA, 11 in GJMI, and 8 in PTVE). The IWV from the HSB sensor was retrieved employing a method based on a lineal regression of the HSB channels (Lima and Machado 2006), in which the IWV in the layer $n$ is expressed by

$$
\operatorname{IWV}(n)=a(n)+\sum_{i=1}^{N} b_{i}(n) T_{b}\left(\nu_{i}\right)
$$


where $N$ is the number of HSB channel combinations used, $a(n)$ and $b_{i}(n)$ are regression coefficients, and $T_{b}\left(\nu_{i}\right)$ is the brightness temperature measurement at $\nu_{i}$ frequency. The coefficients for this regression were obtained using the radiosondes launched in the RACCI experiment and the Radiative Transfer for Television and Infrared Observation Satellite Operational Vertical Sounder (RTTOV)-7 model to simulate the brightness temperatures of the HSB channels (Lima and Machado 2006).

The zenithal tropospheric delay $\left(Z_{\mathrm{TD}}\right)$ was obtained by processing the GPS data using the Gipsy Oasis-II (GOA-II) software (Gregorius 1996) using the precise point-positioning postprocessed method. The zenithal wet delay $\left(Z_{\mathrm{WD}}\right)$ was obtained from $Z_{\mathrm{TD}}$ after removing the zenithal hydrostatic delay using an appropriated model (Davis et al. 1985), which requires the atmospheric pressure measurements. The $Z_{\mathrm{WD}}$ were converted into IWV by using the tropospheric mean temperature $\left(T_{m}\right)$ together with the relationship suggested by Bevis et al. (1992),

$$
\mathrm{IWV}=Z_{\mathrm{WD}} \frac{10^{6}}{R_{w}\left(k_{2}^{\prime}+\frac{k_{3}}{T_{m}}\right)},
$$

where $R_{w}=(461.5181) \mathrm{J} \mathrm{kg}^{-1} \mathrm{~K}^{-1}$ is the specific gas constant for water vapor, and $k_{2}^{\prime}$ and $k_{3}$ are atmospheric refractivity constants (Bevis et al. 1994). The $T_{m}$ was obtained from temperature $\left(T_{s}\right)$ and pressure $\left(P_{s}\right)$ measured at surface, and by applying a $T_{m}$ model for the Amazonian region that presents root-mean-square (RMS) values to the order of $1.8 \mathrm{~K}$. The sampling rate of GPS IWV values was $5 \mathrm{~min}$.

In the data pair match different IWV quantification techniques, the values from the radiosonde were referenced in time, taking into consideration the median time for this device to cross the atmospheric wet layer (about $25 \mathrm{~min}$ ). In the comparison of the radiosonde with GPS, a median GPS IWV value was calculated using the five nearest values in the radiosonde reference time. In the comparison of the radiosonde and AERONET, the IWV AERONET was interpolated using the two IWV values nearest in time (less than 25 $\mathrm{min}$ ) to the radiosonde reference time. IWV GPS was interpolated to AERONET IWV reference time in the comparison between these techniques.

\section{Results and discussion}

IWV time series from the GPS receivers, RS80 radiosondes, two AERONET versions, and an HSB sensor in the RACCI stations is shown in the Fig. 2, which allows for a quick assessment of the relative characteristics of each observation system involved in this experiment. Because the radiosondes measure humidity directly, IWV from RS80 was used to analyze the results obtained from other techniques in detail. The results are presented using scatterplots (Figs. 3, 4, 5, and 6), and the statistical information is shown in Fig. 7.

\section{a. Comparison of the AERONET solar radiometer with the $R S 80$ radiosonde}

Figure 3 shows the scattering diagram from 38 data pairs between IWV from AERONET level 1.5 and RS80 radiosonde. An overestimation of IWV derived from AERONET level 1.5 can clearly be seen. Standard deviation (SD) is much smaller than the bias, revealing that systematic error occurs in this comparison. In addition, the correlation coefficient $(r)$ between these techniques is large ( $r$ of 0.93 ) and the slope indicates that AERONET and RS80 present similar sensitivity to IWV, although the interception value is also considerable. Figure 3 also shows the discrepancies between the two techniques as a function of the RS80 IWV value. The discrepancies (Fig. 3b) show that the largest disagreement between these techniques is in the interval between 33 and $45 \mathrm{~kg} \mathrm{~m}^{-2}$, in which the dispersion is very large. The discrepancies in some cases were near $10 \mathrm{~kg} \mathrm{~m}^{-2}$. While a large bias was observed for the AERONET level 1.5, for level 2.0 smaller discrepancies were observed. Figure 4 shows the scattering diagram for IWV from AERONET level 2.0 as a function of RS80 IWV. Comparison of Fig. 4a with Fig. 3a shows that AERONET IWV from level 2.0 is drastically drier than that of level 1.5. Therefore, the large overestimate presented in level 1.5 was removed in level 2.0 (bias of $-2.1 \mathrm{~kg} \mathrm{~m}^{-2}$ ). In addition, level 2.0 also presented an important improvement in the precision of IWV, and consequently the RMS is significantly lower in level $2.0\left(2.7 \mathrm{~kg} \mathrm{~m}^{-2}\right)$ than in level $1.5(6.8 \mathrm{~kg}$ $\mathrm{m}^{-2}$ ). The plot in Fig. $3 \mathrm{~b}$ makes it clear that those discrepancies increase significantly when IWV becomes larger. Version 2.0 corrected the wetter trend from version 1.5 , consequently, this version presents nearly all values drier than the radiosonde.

\section{b. Comparison HSB sensor with the RS80 radiosonde}

The results obtained in the comparison between IWV from the RS80 and HSB sensor are presented in Fig. 5. Because of the constraint of nearly clear sky on producing HSB IWV values, which was very scarce during the RACCI experiment, only a small number of RS80-HSB coincident measurements (nine data pairs) 

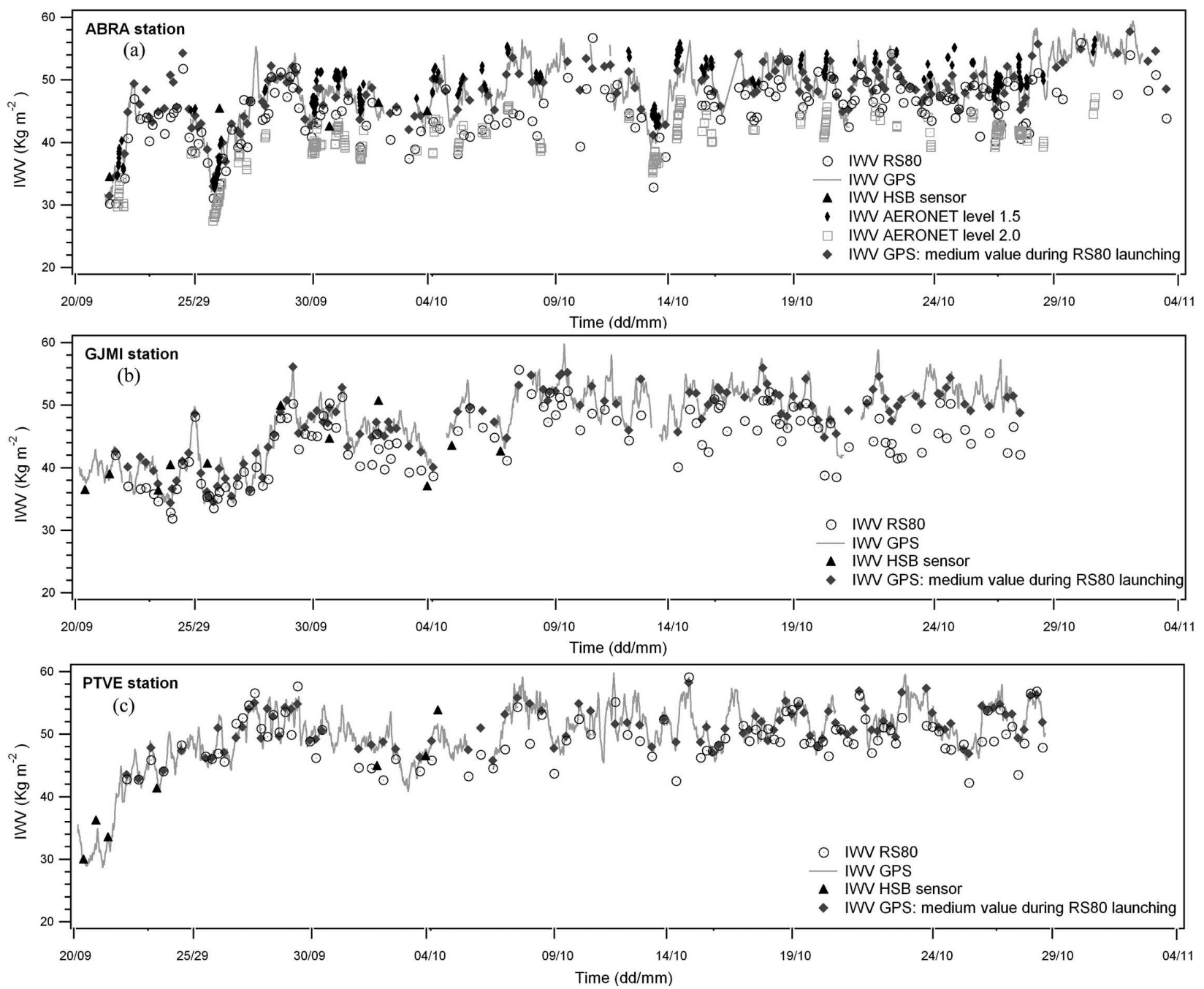

FIG. 2. IWV time series from GPS receivers, RS80 radiosondes, two AERONET versions and HSB sensor in the three RACCI stations.

were considered. Because this sample is not statistically significant, only a qualitative analysis is presented in this comparison. HSB IWV dispersion is very large in comparison with radiosondes. The discrepancies (Fig. $5 b)$ show that this wetter tendency decreases when IWV become larger. The discrepancies are initially positive and decrease, becoming negative when IWV values are larger than $42 \mathrm{~kg} \mathrm{~m}^{-2}$.

\section{c. Comparison GPS receiver with the RS80 radiosonde}

Figure 6 shows a scattering diagram and discrepancies from the GPS IWV as a function of the ones from the RS80 IWV. The scatterplots from Fig. 6 reveal that the GPS technique presented a tendency to overestimate humidity in relation to the RS80 radiosonde. The observed biases were $3.2,3.3$, and $1.7 \mathrm{~kg} \mathrm{~m}^{-2}$ (or $6.3 \%$, $6.5 \%$, and $3.4 \%$ ) at the ABRA (Fig. 6a), GJMI (Fig. 6c), and PTVE (Fig. 6e) stations, respectively. The GPS receiver's sensitivity to IWV oscillation compared with the RS80 shows a substantial difference in the RACCI station, as indicated by the slope of the regression line. In the GJMI station, where the bias value is larger, the slope (0.95) value was closer to unity than the one from PTVE (0.68), where the lowest bias was found. Another point worthy of attention in Fig. 6 is the large dispersion between the IWV from these techniques, mostly in the ABRA and GJMI stations, where the RMS in both stations was $4 \mathrm{~kg} \mathrm{~m}^{-2}$. The IWV from PTVE presented the lowest dispersion (RMS value generated was $2.9 \mathrm{~kg} \mathrm{~m}^{-2}$ ), but the correlation coefficient ( $r$ of 0.79$)$ value reveals that the correlation be- 

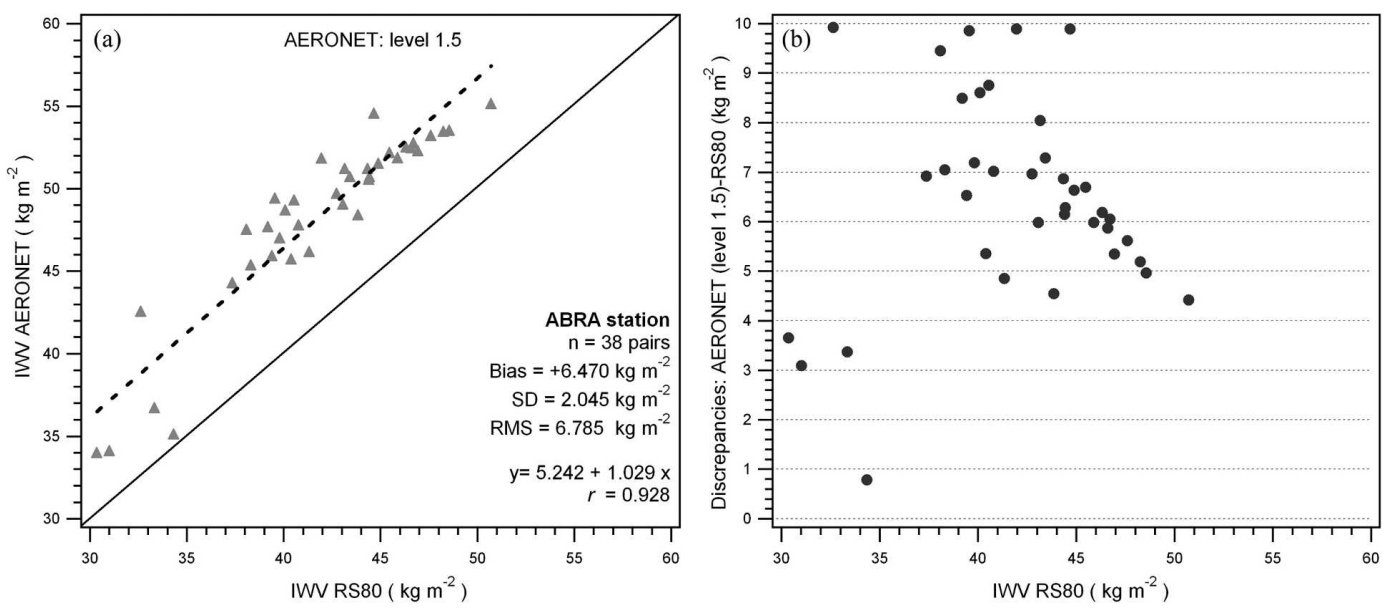

FIG. 3. Scatter diagrams of the AERONET IWV from (a) level 1.5 and (b) discrepancies as a function of the RS80 IWV in the ABRA station.

tween IWV from the RS80 radiosondes in this station is worse than those from the ABRA and GJMI stations $(r$ of 0.86 and 0.90 , respectively). The discrepancy plots (Figs. 6b,d,f) show that the disagreement between these techniques is larger when the IWV is within the 37-52 $\mathrm{kg} \mathrm{m}^{-2}$ interval.

\section{1) Analysis of the Results}

Figure 7 summarizes the results of the various techniques used for measuring IWV, presenting statistical measurements and coefficients generated in the comparisons of all the possible combinations with the RS80. An analysis of the numbers presented in this figure shows the following.

- The RS80 tends to underestimate IWV when other techniques are considered as a reference (with the exception of AERONET level 2.0). This result is similar to ones obtained by other works, which reported that the RS80 appears to have a dry bias (Turner et al. 2003; Revercomb et al. 2003; Sapucci et al. 2005).

- It can be seen that IWV quantification from the GPS tends to generate smaller values than those obtained from AERONET level 1.5 (bias of $-2.33 \mathrm{~kg} \mathrm{~m}^{-2}$ or $4.5 \%$ ), and the correlation coefficient $(r)$ between these techniques is the largest ( $r$ of 0.97). A previous intercomparison experiment has shown that the AERONET IWV is about $6.8 \%$ wetter than the microwave radiometer (MR) (Schmid et al. 2001). Using GPS data processing similar to that used here (same software and method), Emardson et al. (2000) considered 141864 data pairs to show that GPS IWV is only $2.5 \%$ wetter than MWR IWV values. These
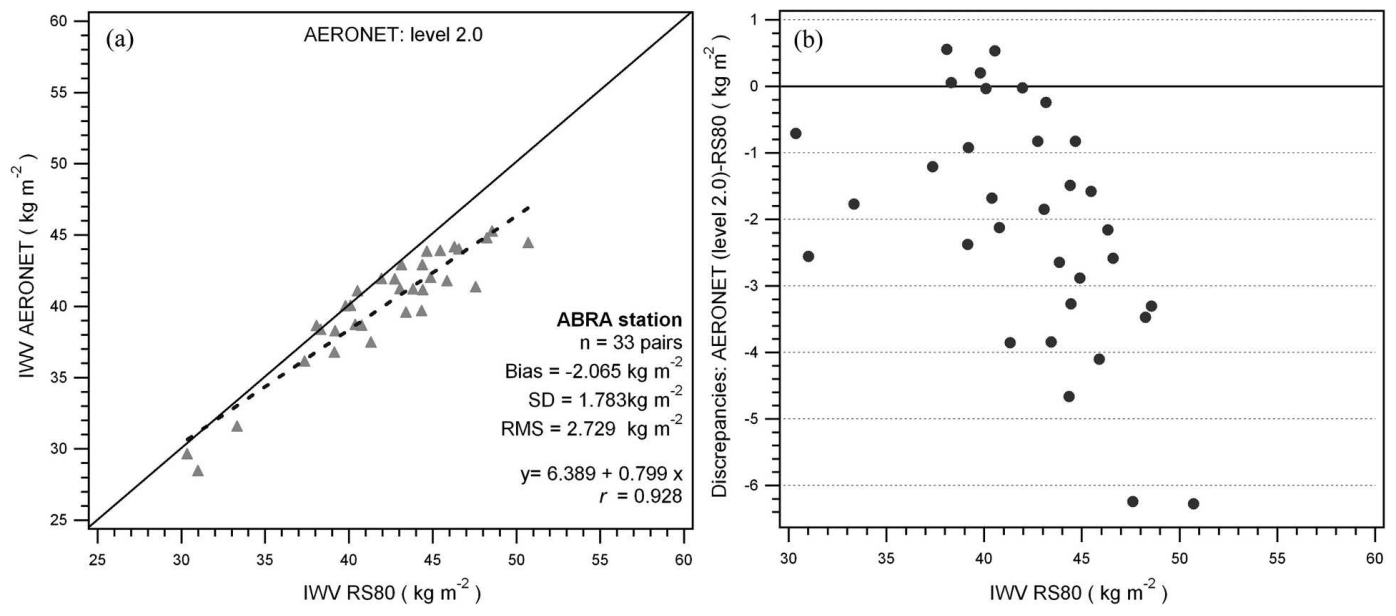

FIG. 4. Same as in Fig. 2, but using AERONET IWV from level 2.0. 

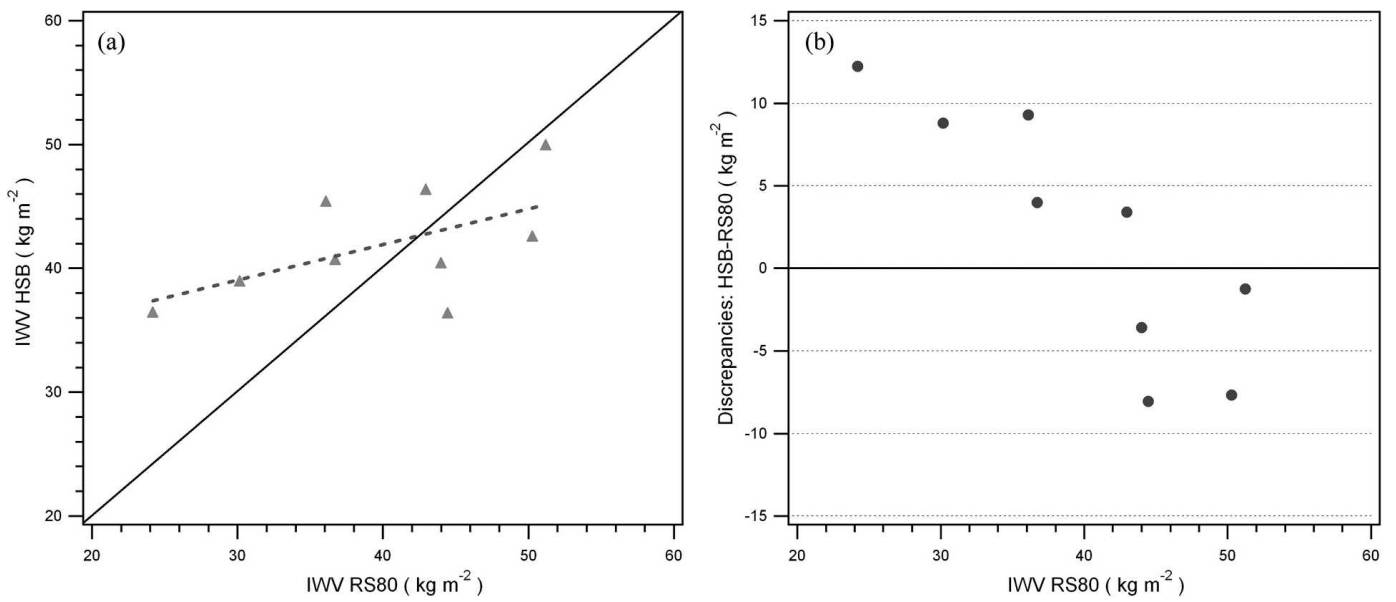

FIG. 5. Scatter diagrams of the (a) HSB IWV and (b) discrepancies as a function of the RS80 IWV in the ABRA, GJMI and PTVE stations.

results suggest that GPS IWV is $4.3 \%$ drier than Cimel IWV values, which is near to the result generated in this comparison (4.5\%). However, when GPS IWV is compared to AERONET level 2.0, this tendency is very large and opposite (bias of $-5.9 \mathrm{~kg} \mathrm{~m}^{-2}$ ). In both AERONET levels the SD between these techniques was low.

- The tendency to overestimate humidity in the GPS technique, with regard to the RS80 radiosonde, is similar to results obtained in previous works, but at a lower magnitude. Using 1726 radiosondes and the same method used here, Emardson et al. (2000) showed that IWV from GPS data was $0.8 \mathrm{~kg} \mathrm{~m}^{-2}$ wetter than that from radiosonde data, and Ingold et al. (2000), using the double differences processing method, found a wetter bias of $1.76 \mathrm{~kg} \mathrm{~m}^{-2}$. However, none of these studies was held over a wetter tropical region like the Amazon.

- The bias between IWV from AERONET levels 1.5 and 2.0 is of $8.5 \mathrm{~kg} \mathrm{~m}^{-2}$ (around of 17\%) and is larger than expected. Schmid et al. (2001) reported that the IWV generated by the methodology applied in level 2.0 is $13 \%$ lower than in comparison with AERONET level 1.5.

The differences between IWV estimates from the levels 1.5 and 2.0 AERONET algorithms reached $6 \mathrm{~kg}$ $\mathrm{m}^{-2}$ at IWV values of $40 \mathrm{~kg} \mathrm{~m}^{-2}$, decreasing with IWV (A. Smirnov 2006, personal communication). The RACCI experiment results indicate a higher difference (roughly $8.5 \mathrm{~kg} \mathrm{~m}^{-2}$ at IWV values of $50 \mathrm{~kg} \mathrm{~m}^{-2}$ ). The reasons for such disagreement are unclear. In that analysis the option of comparing IWV estimates as they were released by the AERONET team was made. Experimental issues, in the sense that both versions can be applied to the same solar transmission measurements, could not explain the differences between the two versions. Possible explanations come from the algorithms themselves. Both AERONET algorithms were based on theoretical calculations of atmospheric transmittance that, in turn, were performed not only on different spectroscopy data, but also through different radiative transfer models. Previous contributions to this matter (e.g., Plana-Fattori et al. 2004) have shown that two given radiative transfer models can effectively provide different IWV estimates. Differences between IWV estimates from two AERONET algorithms might be interpreted in terms of differences in representing a given atmospheric structure by two different radiation modelers. A more complete picture of these two AERONET algorithms requires more experiment, in which other geophysical conditions much be considered.

Although previous papers have reported that the differences between radiosondes and GPS receivers (Wolfe and Gutman 2000; Van Baelen et al. 2005) and solar and microwave radiometers (Schmid et al. 2001) increase with humidity, this is not observed in the RACCI experiment (Figs. 3, 5, and 6). The most likely reason for this peculiar behavior is the range of IWV values. While in the previous experiments the IWV values were in the interval of $0.0-40 \mathrm{~kg} \mathrm{~m}^{-2}$, in the RACCI experiment this interval was $30-59 \mathrm{~kg} \mathrm{~m}^{-2}$.

On the contrary, other comparisons between GPS and the RS80 have involved different devices in the three RACCI stations for a total of 385 data pairs. These characteristics allow further investigation of the behavior of the discrepancies generated in this comparison. A detailed discussion of these results is presented in the following section. 

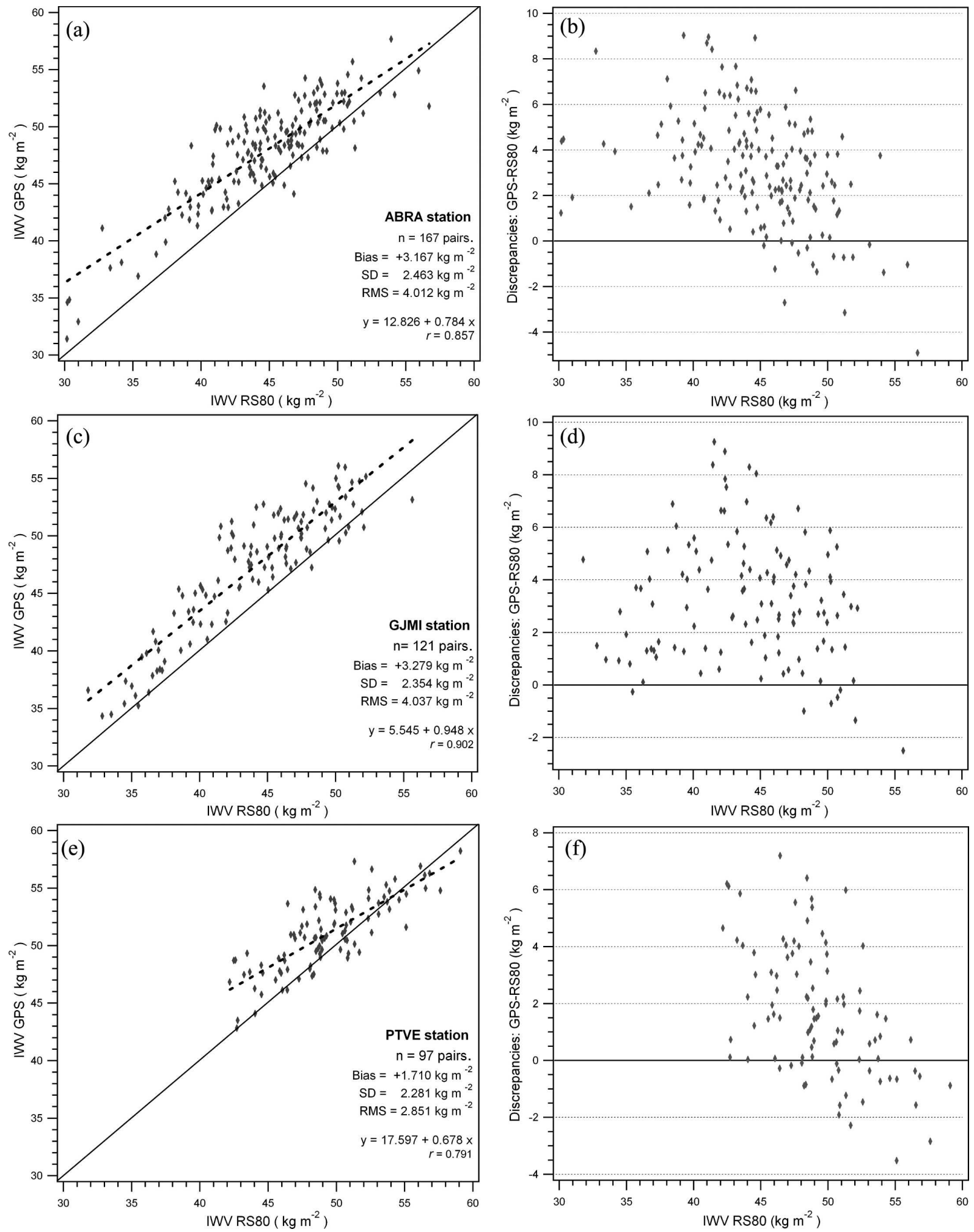

FIG. 6. Scatter diagrams of the GPS IWV from RACCI GPS stations (a), (c), (e) and (b), (d), (f) discrepancies as a function of the RS80 IWV values. 


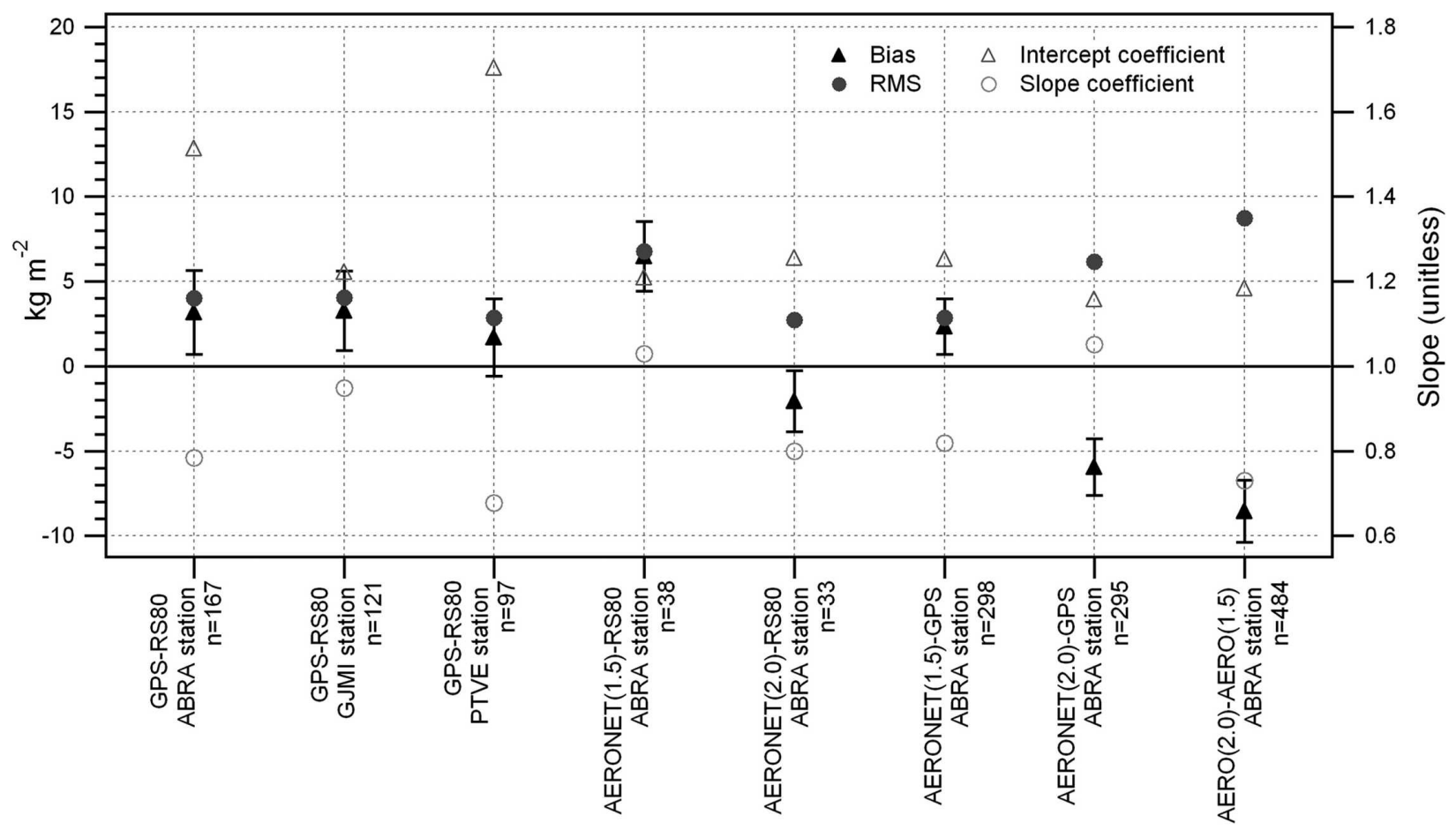

FIG. 7. Statistics for IWV comparison of all the possible combinations of the quantification techniques used in RACCI experiment. The HSB sensor comparisons are excluded from this analysis because the data pair numbers are not statistically significant. The bias (solid triangle), RMS (solid circle), intercept coefficient (open triangle) and slope coefficient (open circle) are shown. Error bars represent $\pm \mathrm{SD}$. The number of data pair used in each comparison is shown in the base of the figure.

\section{2) Discussion OF THE GPS AND RS80 COMPARISON RESULTS}

Ionosphere-induced error can be one of the possible reasons for the bias that GPS IWV presented in comparison with RS80, which has been wetter than other intercomparison experiments. The free electrons in the ionosphere affect the propagation of the GPS signal (Leick 1995), generating error that is inversely proportional to the square of the carrier frequency and proportional to the total electron content (TEC) along the path between the satellite and receiver. The TEC is mainly a function of incident solar radiation flux that can vary by a wide range of phenomenon, such as sunspot cycle, the rotation of the sun, the earth's magnetic field, season, and localization (Spilker 1994; Camargo et al. 2000). Seeber (1993) describes this relation as a power series of $1 / f$ ( $f$ is carrier frequency), where the higher-order terms are frequently ignored. The negligence of these terms in the GPS processing can result in residual errors related to the $Z_{\mathrm{TD}}$ during high solar activity (Brunner and Gu 1991), as in the Amazonian region during the RACCI experiment.

The most important factors influencing the ionospheric activity during the RACCI experiment were its location and the sunspot cycle (periodicity of approxi- mately $11 \mathrm{yr}$ ). The RACCI GPS stations were localized near the geomagnetic equator, in which the incident solar energy is larger than other regions, and the data collection was carried out during a period of high sunspot count, in which the terrestrial atmosphere ionization was intensified (Kunches 2001). The effects of sunspot counts on the GPS signal can be observed in the temporal series of the earth's mean TEC (Fig. 8) (information online at http://www.aiub.unibe.ch/ ionosphere.html). The RACCI experiment was held close to the maximum period of sunspot cycle when the mean TEC values were sufficiently high [TEC of $40 \times$ $10^{16}$ electrons (el) $\mathrm{m}^{-2}$ ], being 4 times larger than the minimum period in this cycle.

Because the error in the GPS signal generated by ionosphere depends on the carried frequency, the TEC can be obtained applying a linear combination of $\mathrm{P}$ code from two carried frequencies: L1 at $1.57542 \mathrm{GHz}$ and L2 at $1.22760 \mathrm{GHz}$ (see Hofmann-Wellenhof et al. 2001 for more details). Figure 9 shows the line-of-sight TEC average as a function of local hours and the statistics generated in the different RACCI stations in order to show the correlation between the ionosphere's direct influence on the GPS signal and bias from the comparison between the GPS and RS80. The statistical 


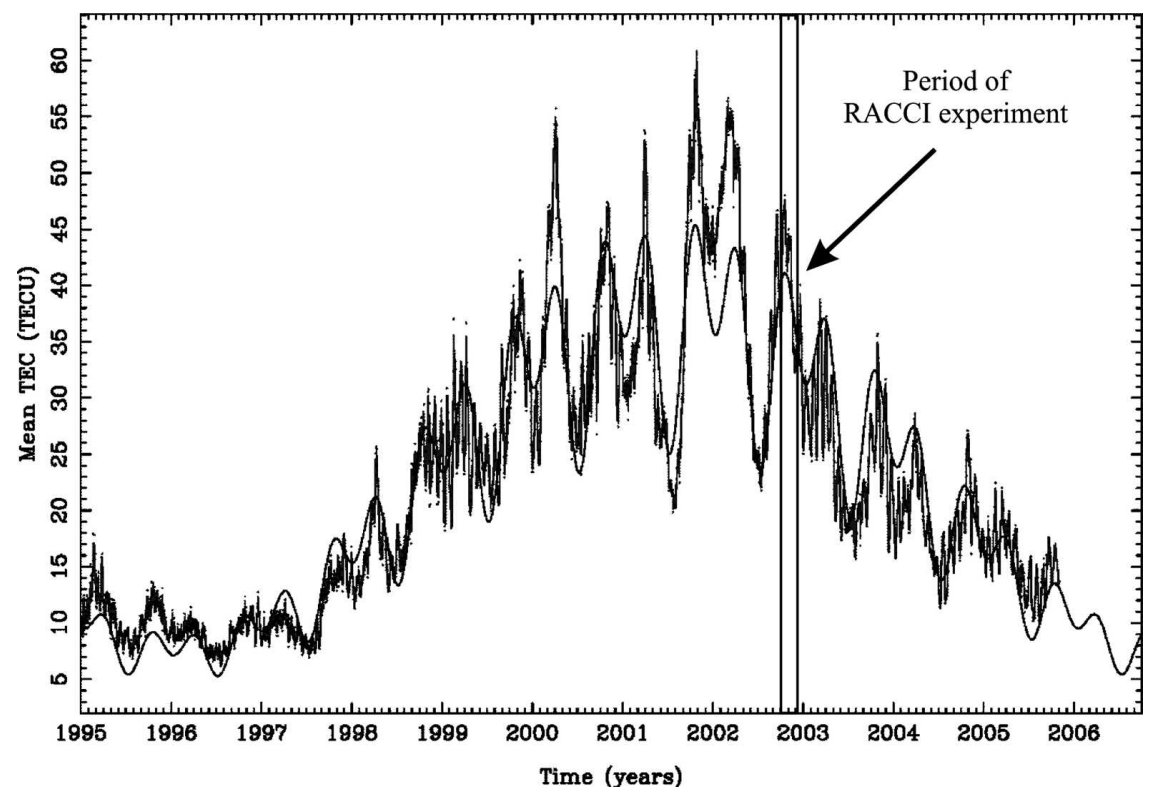

FIG. 8. Time series of the earth's mean TEC from 1 Jan 1995 to 6 Feb 2006 (Source: Center for Orbit Determination in Europe; online at http://www.aiub.unibe.ch/ionosphere.html).

information is shown in this figure as a function of the synoptic launching time of radiosondes because they are most used for operational purposes. The average TEC value varied substantially during the days of the RACCI experiment. Similar to results reported by Batista et al. (1994) related to the ionosphere in the equatorial region, the TEC maximum pick was around 1400 local time (LT) and the minimum was around 0600 LT. During the day the TEC increases induced by incident solar energy, and in the night it is reduced because the free electrons tend to recombine with ions.

As is clearly seen in Fig. 9, the bias is larger when the ionospheric activity is larger. The bias at $1200(+3.9$, +4.1 , and $+2.4 \mathrm{~kg} \mathrm{~m}^{-2}$ in the ABRA, GJMI, and PTVE stations, respectively) and 1800 UTC $(+4.3,+4.1$, and $+3.3 \mathrm{~kg} \mathrm{~m}^{-2}$, respectively) is almost twice as large as the bias from the radiosondes launched at $0000(+1.9$, +2.7 , and $+1.2 \mathrm{~kg} \mathrm{~m}^{-2}$, respectively) and 0600 UTC $\left(+1.1,+2.3\right.$, and $-0.2 \mathrm{~kg} \mathrm{~m}^{-2}$, respectively). Note that the best agreement is found in the radiosondes launched at 0600 UTC (0200 LT) and worst considers radiosondes at $1800 \mathrm{UTC}(1400 \mathrm{LT})$.

The other point that needs to be considered is the RS80's tendency of generating drier IWV during daytime than nighttime. Turner et al. (2003), using a microwave radiometer, suggested that daytime RS80 is typically $3 \%-4 \%$ drier than nighttime. Sapucci et al. (2005), in a WMO radiosonde intercomparison experiment in Brazil, reported drier diurnal behavior to the order of $5.9 \%$ (or $2.9 \mathrm{~kg} \mathrm{~m}^{-2}$, if the RACCI IWV mean of $50.6 \mathrm{~kg} \mathrm{~m}^{-2}$ was considered) when RS80 is compared against the Snow White humidity sensor.

The period of the day in which ionospheric activity is larger coincides with the period where the largest wet bias from RS80 is observed. The combination of these two factors is probably the main reason for the fact that the bias found in this experiment is larger than in previous work results. If one considers only the nighttime radiosondes (where the ionospheric activity is reduced and the drier bias of the RS80 is lower), the bias value is of the same order as the results reported by Emardson et al. (2000) and Ingold et al. (2000), even though we are working over a very wet, tropical region. Considering that the RACCI experiment did not have another independent and reliable humidity measurement technique, using a microwave radiometer, for example, it was not possible to assess what the error magnitude was caused by these factors individually.

Van Baelen et al. (2005), using data from a GPS receiver (using a double-differences processing method), RS90 radiosondes, and microwave radiometer, collected during a 3-month campaign in Toulouse, France, in the same period of the RACCI experiment, reported results similar to the ones found here. The difference between the IWV from a radiosonde and a GPS receiver was clearly much larger at daytime (bias of $2.0 \mathrm{~kg} \mathrm{~m}^{-2}$ ) than at nighttime (bias of $-0.1 \mathrm{~kg} \mathrm{~m}^{-2}$ ). Although the authors have not mentioned the high ionospheric activity in this period, it likely contributed to such results. Additionally, these authors reported 

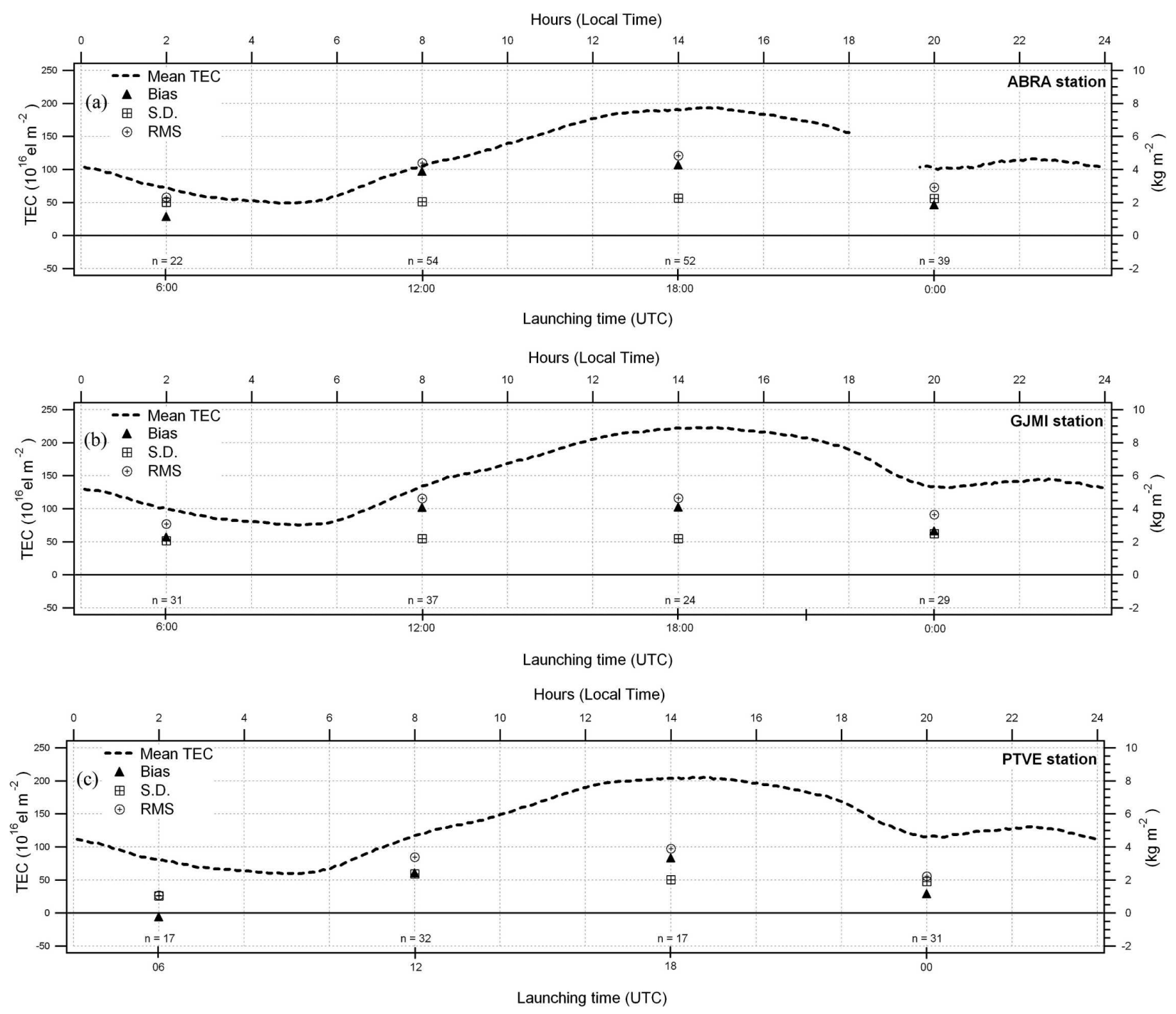

FIG. 9. The line-of-sight TEC average as a function of LT and statistical measurements of the comparison between the GPS and RS80 in function radiosonde launching synoptic time.

that the differences between the GPS and radiosondes present a dependency on IWV values almost linearly from a significant negative bias $\left(-1.0 \mathrm{~kg} \mathrm{~m}^{-2}\right)$ in dry atmospheric conditions (less than $15 \mathrm{~kg} \mathrm{~m}^{-2}$ ) to a much larger positive bias $\left(+3.0 \mathrm{~kg} \mathrm{~m}^{-2}\right)$ in atmospheric conditions with larger humidity content (larger than $35 \mathrm{~kg}$ $\mathrm{m}^{-2}$ ). Similar analysis in the results presented in the RACCI experiment shows that such near-linear dependency is not maintained for IWV values larger than 45 $\mathrm{kg} \mathrm{m}^{-2}$. The data pairs in the comparison of GPS against radiosondes were separated into two classes: the first when IWV radiosonde values are between 35 and $45 \mathrm{~kg} \mathrm{~m}^{-2}(n=147)$, and the second between 45 and $55 \mathrm{~kg} \mathrm{~m}^{-2}(n=215)$, which generated a bias of 4.1 and $2.2 \mathrm{~kg} \mathrm{~m}^{-2}$, respectively. The classes composed of
IWV values either less than $35 \mathrm{~kg} \mathrm{~m}^{-2}(n=12)$ or larger than $55 \mathrm{~kg} \mathrm{~m}^{-2}(n=11)$ were excluded from this analysis because the data pair number is not statistically significant. The possible causes of this behavior are unknown. Hence, other experiments in regions with a larger humidity concentration (IWV values larger than $45 \mathrm{~kg} \mathrm{~m}^{-2}$ ) involving other techniques are necessary to assess the causes of the nonlinear dependency of differences between humidity measurements from radiosondes and GPS on IWV values.

Another result that must be discussed is the different magnitudes of the bias generated in PTVE $(1.71 \mathrm{~kg}$ $\mathrm{m}^{-2}$ ) and the other RACCI GPS stations (around 3.2 $\mathrm{kg} \mathrm{m}^{-2}$ in ABRA and GJMI). In ABRA, in contrast with the other RACCI stations, the number of radio- 


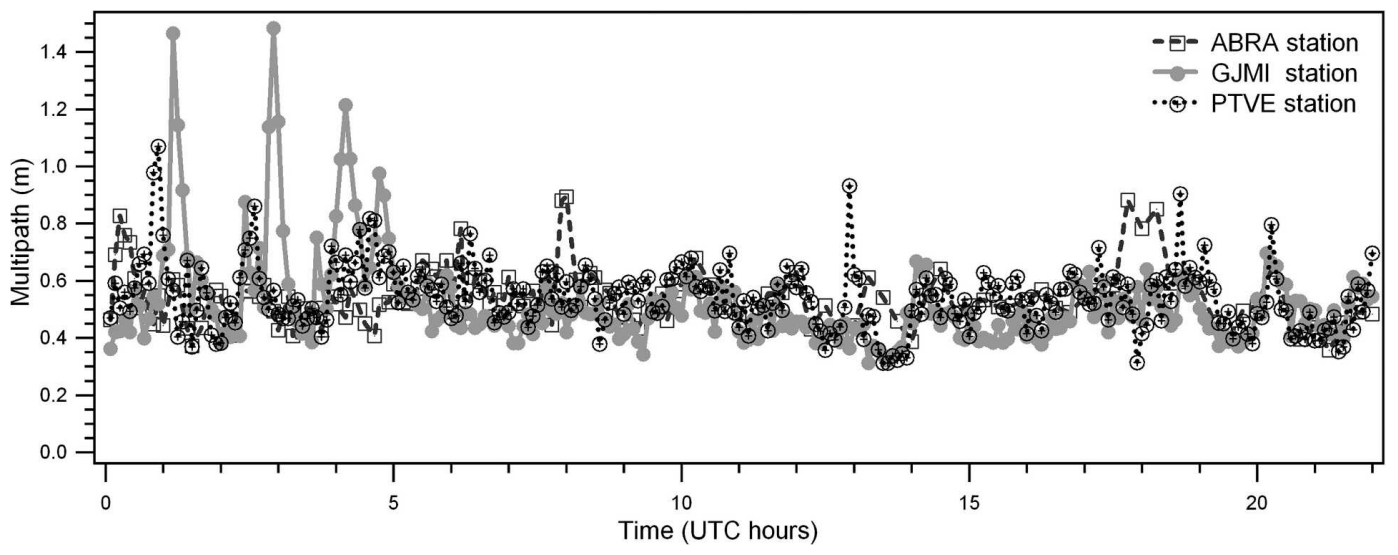

FIG. 10. Mean of multipath in the GPS signal in the three RACCI GPS stations (6 Oct 2002).

sondes launched during the daytime period (106 radiosondes) was much larger than the one launched during the nighttime period (61 radiosondes). Consequently, the influence of the ionosphere modeling residuals and RS80 daytime drier bias in the final bias in this station was more significant than the others. To investigate this assumption, analysis was carried out where only the simultaneous IWV-GPS and IWV-RS80 value pairs in three RACCI GPS stations were considered. The number of resultant data pairs was 61. In this circumstance, the bias value in the ABRA station was reduced from +3.2 to $+2.3 \mathrm{~kg} \mathrm{~m}^{-2}$, while in the other stations the bias remained practically unchanged (the bias remained +3.2 and $+1.5 \mathrm{~kg} \mathrm{~m}^{-2}$ in GJMI and PTVE, respectively), as expected. The most probable reason for the different bias between the GJMI and PTVE stations is due to the multipath effects (see Hofmann-Wellenhof et al. 2001 for a detailed description) in the GPS signal reception. Because the receiver brand and models are the same, the problem may be associated with the locale where the receivers were installed. Because the GJMI GPS receiver was installed over a roof (only few centimeters above it), this condition may generate more multipaths than the PTVE receiver, which was installed in an open area. To investigate this possibility, a quality control algorithm was applied based on Translation Edit Quality Check (TEQC) software (Estey and Meertens 1999). Therefore, it was possible to obtain the mean of the multipath of the GPS observables for the different stations, which are shown for one day as an example in Fig. 10 (22 October 2002). From this figure one can observe that in the GJMI station there was a period (0000-0500 UTC) where the multipath effect is more significant than in the other stations. This period coincides with that where the ionospheric activity is reduced and the RS80 drier bias is smaller. Consequently, the bias value in the GJMI station was kept relatively high during that period, while in the other stations it was considerably reduced. If only the radiosondes launched at 0600 UTC are considered, the bias value in the GJMI station was $+2.3 \mathrm{~kg} \mathrm{~m}^{-2}$, while in ABRA and PTVE they were +1.1 and $-0.2 \mathrm{~kg} \mathrm{~m}^{-2}$, respectively.

The SD was similar for the three stations (about of $4.5 \%$ or $2.3 \mathrm{~kg} \mathrm{~m}^{-2}$ ) and relatively better than the ones found in the other experiments. Emardson et al. (2000), using 1726 radiosondes launched in the European region (IWV medium of $20 \mathrm{~kg} \mathrm{~m}^{-2}$ ), found SD to the order of $7.5 \%\left(1.5 \mathrm{~kg} \mathrm{~m}^{-2}\right)$. Figure 8 shows that the SD is nearly constant for different radiosonde launching times (about $2.0 \mathrm{~kg} \mathrm{~m}^{-2}$ ) for all stations, even under high ionospheric activity. This result is important because the SD is associated with stochastic error, and such reduced values provide an indication that the applied methodology is appropriated. Of course, the bias values, which are associated with systematic errors from the signal's multipath, high-order ionosphere effects, and other nonmodeled effects, significantly affected the RMS generated between the GPS and RS 80 radiosondes. In the absence of such bias the resultant RMS would be similar to SD values.

\section{Summary and conclusions}

IWV retrieved from different techniques were analyzed during the RACCI experiment carried out in Amazonian region on September and October 2002. Three remote IWV quantification techniques were used-two were ground based (GPS receivers and an AERONET photometer) and one was space based (HSB sensor)-whose results were compared with RS80 radiosondes, which, unlike the other techniques, accomplish the measurements in a direct way. 
In summary, the results generated in the different comparisons suggest that RS80 presents a tendency to underestimate the IWV when compared against the other indirect techniques. The presence of some residuals of correction for the RS80 dry bias described by Wang et al. (2002) could have influenced this result. When compared to the GPS IWV values, it was shown that the AERONET level 1.5 overestimates the IWV by $+2.3 \mathrm{~kg} \mathrm{~m}^{-2}(+4.5 \%)$, while AERONET level 2.0 and RS 80 underestimate by $-5.9(11.5 \%)$ and $-2.9 \mathrm{~kg} \mathrm{~m}^{-2}(5.7 \%)$, respectively.

The new version of the IWV from AERONET (level 2.0) was able to remove the systematic error present in level 1.5, which overestimates the IWV when compared with RS80. In the RACCI circumstance the AERONET level 2.0 generated IWV that was lower than that from RS80 (a bias of $-2.1 \mathrm{~kg} \mathrm{~m}^{-2}$ ), which led us to suspect that it underestimates the atmospheric humidity.

The difference generated between IWV from the GPS receiver and the RS80 was high probably because of the combination of the influence of ionospheric effects (the RACCI experiment was carried out during a period of high ionospheric activity) in the GPS signal and drier daytime bias of the RS80. If only the radiosondes launched during nighttime in the three stations are considered, the RMS value was $2.7 \mathrm{~kg} \mathrm{~m}^{-2}$ (only $5.4 \%$ ), while for the ones launched during daytime the RMS value was $4.8 \mathrm{~kg} \mathrm{~m}^{-2}$ (8.6\%).

Acknowledgments. Hearty acknowledgements are addressed to Maria Assunção F. Silva Dias (IAG-USP), coordinator of the RACCI experiment, for her continuous interest on the subject as well as for the support in installing and operating the three sites under consideration. The authors thank the Max-Planck team at the ABRA site for its kind support throughout the campaign; Santiago \& Cintra Importação e Exportação Ltda. for providing the Legacy GPS receivers; Fundação Universidade Federal de Rondônia (UNIR) and Destacamento de Proteção ao Vôo de Porto Velho (DPVPV) for their assistance in data collection; Brent Holben (NASA GSFC) for his effort in establishing and maintaining the Abracos-Hill AERONET site; Wagner Flauber Araujo for HSB IWV values; Eder Paulo Vendrasco for the radiosonde quality control; and Wagner Carrupt Machado and Marcelo Tomio Matsuoka for helpful discussions about ionosphere activity in Amazonian region. This research was mainly supported by the Brazilian agency Fundação de Amparo à Pesquisa do Estado de São Paulo (FAPESP) under Grants Process N. 01/06908-7 and N. 01/12761-9.

\section{REFERENCES}

Batista, I. S., J. R. de Souza, M. A. Abdu, and E. R. de Paula, 1994: Total electron content at low latitudes and its comparison with the IRI90. Adv. Space Res., 14, 87-90.

Bevis, M. G., S. Businger, T. Herring, C. Rocken, R. A. Anthes, and R. H. Ware, 1992: GPS meteorology: Remote of atmospheric water vapor using the global positioning system. $J$. Geophys. Res., 97, 15 787-15 801.

- - S. Chiswell, T. Herring, R. A. Anthes, C. Rocken, and R. H. Ware, 1994: GPS meteorology: Mapping zenith wet delays onto precipitable water. J. Appl. Meteor., 33, 379-386.

Brunner, F. K., and M. Gu, 1991: An improved model for the dual frequency ionospheric correction of GPS observations. Manuscr. Geod., 16, 205-214.

Camargo, P. O., J. F. G. Monico, and L. D. Ferreira, 2000: Application of ionospheric corrections in the equatorial region for L1 GPS users. Earth Planets Space, 52, 1083-1089.

Davis, J. L., T. A. Herring, I. Shapiro, A. E. Rogers, and G. Elgened, 1985: Geodesy by interferometry: Effects of atmospheric modeling errors on estimates of baseline length. $R a$ dio Sci., 20, 1593-1607.

Duan, J., and Coauthors, 1996: GPS meteorology: Direct estimation of the absolute value of precipitable water. J. Appl. Meteor., 35, 830-838.

Emardson, T. R., J. M. Johansson, and G. Elgered, 2000: The systematic behavior of water vapor estimates using four years of GPS observations. IEEE Trans. Geosci. Remote Sens., 38, 324-329.

Estey, L. H., and C. M. Meertens, 1999: TEQC: The multipurpose toolkit for GPS/GLONASS data. GPS Solutions, 3, $42-49$.

Fujiwara, M., M. Shiotani, F. Hasebe, H. Vömel, S. J. Oltmans, P. W. Ruppert, T. Horinouchi, and T. Tsuda, 2003: Performance of the Meteolabor "Snow White" chilled-mirror hygrometer in the tropical troposphere: Comparisons with the Vaisala RS80 A/H-Humicap sensors. J. Atmos. Oceanic Technol., 20, 1534-1542.

Gregorius, T., 1996: GIPSY-OASIS II How it works. Department of Geomatics, University of Newcastle upon Tyne, 167 pp. [Available online at http://www.ceg.ncl.ac.uk/research/ geomatics/geodesy/assets/gipsy-oasisIIHowItWorks.pdf.]

Guichard, F., D. Parsons, and E. Miller, 2000: Thermodynamic and radiative impact of the correction of sounding humidity bias in the tropics. J. Climate, 13, 3611-3624.

Hofmann-Wellenhof, B., H. Lichtenegger, and J. Collins, 2001: Global Positioning System: Theory and Practice. 5th ed. Springer-Verlag, $382 \mathrm{pp}$.

Holben, B. N., and Coauthors, 1998: AERONET-A federated instrument network and data archive for aerosol characterization. Remote Sens. Environ., 66, 1-16.

Hou, A. Y., D. V. Ledvina, A. da Silva, S. Zhang, J. Joiner, R. Atlas, G. Huffman, and C. Kummerow, 2000: Assimilation of $\mathrm{SSM} / \mathrm{I}$-derived surface rainfall and total precipitable water for improving the GEOS analysis for climate studies. Mon. Wea. Rev., 128, 509-537.

Ingold, T., B. Schmid, C. Mätzler, P. Demoulin, and N. Kämpfer, 2000: Modeled and empirical approaches for retrieving columnar water vapor from solar transmittance measurements in the $0.72,0.82$ and $0.94 \mu \mathrm{m}$ absorption bands. J. Geophys. Res., 105, 24 327-24 344.

Kunches, J. M., 2001: In the teeth of cycle 23. Preprints, 13th 
IONGNSS Int. Technical Meeting, Salt Lake City, UT, Institute of Navigation, 626-633.

Kuo, Y.-H., Y.-R. Guo, and E. R. Westwater, 1993: Assimilation of precipitable water measurements into mesoscale numerical model. Mon. Wea. Rev., 121, 1215-1238.

—, X. Zuo, and Y.-R. Guo, 1996: Variational assimilation of precipitable water using a nonhydrostatic mesoscale adjoint model. Part I: Moisture retrieval and sensitivity experiments. Mon. Wea. Rev., 124, 122-147.

Lambrigtsen, B. H., and R. V. Calheiros, 2003: The humidity sounder for Brazil-An international partnership. IEEE Trans. Geosci. Remote Sens., 41, 352-361.

Ledvina, D. V., and J. Pfaendtner, 1995: Inclusion of Special Sensor Microwave/Imager (SSM/I) total precipitable water estimates into the GEOS-1 data assimilation system. Mon. Wea. Rev., 123, 3003-3015.

Leick, A., 1995: GPS Satellite Surveying. 2d ed. Wiley, 560 pp.

Lima, W. F. A., and L. A. T. Machado, 2006: Analysis of integrated water vapor estimate from HSB sensor: A study applied to RACCI/LBA (in Portuguese). Braz. J. Meteor., 21, 211-219.

Manzi, A., and S. A. Planton, 1996: A simulation of Amazonian deforestation using a GCM calibrated with ABRACOS and ARME data. Amazonian Deforestation and Climate, J. H. C. Gash, C. A. Nobre, J. M. Roberts, and R. L. Victoria, Eds., Wiley, 505-529.

Marel, H., 2001: Exploitation of ground based GPS for numerical weather prediction and climate applications in Europe. Proc. IAG 2001 Scientific Assembly, Budapest, Hungary, International Association of Geodesy, CD-ROM.

Miller, E. R., J. Wang, and H. L. Cole, 1999: Correction for dry bias in Vaisala radiosonde RH data. Proc. Ninth Atmospheric Radiation Measurement (ARM) Science Team Meeting, San Antonio, TX, U.S. Department of Energy. [Available online at http://www.arm.gov/publications/proceedings/conf09/ extended_abs/miller_er.pdf.]

Miloshevich, L. M., H. Vömel, A. Paukkunen, A. J. Heymsfield, and S. J. Oltmans, 2001: Characterization and correction of relative humidity measurements from Vaisala RS80-A radiosondes at cold temperatures. J. Atmos. Oceanic Technol., 18, $135-156$.

Nobre, C. A., P. J. Sellers, and J. Shukla, 1991: Amazonian deforestation and regional climate change. J. Climate, 4, 957-988.

Paukkunen, A., V. Antikainen, and H. Jauhiainen, 2001: Accuracy and performance of the new Vaisala RS90 radiosonde in operational use. Preprints, 11th Symp. on Meteorological Observations and Instrumentation, Albuquerque, NM, Amer. Meteor. Soc., 98-103.

Plana-Fattori, A., P. Dubuisson, B. A. Fomin, and M. P. Correa, 2004: Estimating the atmospheric water vapor content from multi-filter rotating shadow-band radiometry at Sao Paulo, Brazil. Atmos. Res., 71, 171-192.

Reigber, C., G. Gendt, G. Dick, and M. Tomassini, 2002: Nearreal-time water vapor monitoring for weather forecast. GPS World, Vol. 13, Advanstar Communications, 18-27.

Revercomb, H. E., and Coauthors, 2003: The ARM program's water vapor intensive observation periods-Overview, initial accomplishments, and future challenges. Bull. Amer. Meteor. Soc., 84, 217-236.

Rocken, C., T. Van Hove, and R. H. Ware, 1997: Near real-time GPS sensing of atmospheric water vapor. Geophys. Res. Lett., 24, 3221-3224.

Rosenkranz, P. W., 2001: Retrieval of temperature and moisture profiles from AMSU-A and AMSU-B measurements. IEEE Trans. Geosci. Remote Sens., 39, 2429-2435.

Sapucci, L. F., J. F. G. Monico, A. Plana-Fattori, L. A. T. Machado, and W. F. A. Lima, 2004: GPS performance in the quantification of integrated water vapor in Amazonian regions. Proc. 17th IONGNSS Int. Technical Meeting, Long Beach, CA, Institute of Navigation, 2362-2369.

- , L. A. T. Machado, R. B. Silveira, G. Fisch, and J. F. G. Monico, 2005: Analysis of relative humidity sensors at the WMO radiosonde intercomparison experiment in Brazil. $J$. Atmos. Oceanic Technol., 22, 664-678.

— J. A. Aravéquia, R. A. F. de Souza, S. H. S. Ferreira, R. V. Andreoli, D. L. Herdies, and J. G. F. de Mattos, 2006: The inclusion of integrated water vapor estimates from AIRS/ AMSU and SSM/I sensors into PSAS data assimilation system in the CPTEC. Preprints, 15th Int. TOVS Study Conf., Marateia, Italy, International TOVS Working Group, CDROM. [Available online at http://cimss.ssec.wisc.edu/itwg/ itsc/itsc15/.]

Schmid, B., and Coauthors, 2001: Comparison of columnar watervapor measurements from solar transmittance methods. Appl. Opt., 40, 1886-1896.

Seeber, G., 1993: Satellite Geodesy: Foundations, Methods and Applications. Walter de Gruyter, $531 \mathrm{pp}$.

Silva Dias, M. A. F., and Coauthors, 2002: Cloud and rain processes in a biosphere-atmosphere interaction context in the Amazon Region. J. Geophys. Res., 107, 8072, doi:10.1029/ 2001JD000335.

Spilker, J. J., Jr., 1996: Tropospheric effects on GPS. Global Positioning System: Theory and Applications, B. W. Parkinson and J. J. Spilker Jr., Eds., Vol. 1, American Institute of Aeronautics and Astronautics, 517-546.

Tsuda, T., and Coauthors, 1998: GPS meteorology project of JapanExploring frontiers of geodesy. Earth Planets Space, 50, i-v.

Turner, D. D., B. M. Lesht, S. A. Clough, J. C. Liljegren, H. E. Revercomb, and D. C. Tobin, 2003: Dry bias and variability in Vaisala RS80-H radiosondes: The ARM experience. $J$. Atmos. Oceanic Technol., 20, 117-132.

Van Baelen, J., J. P. Albagnag, and A. Dabas, 2005: Comparison of near-real time estimates of integrated water vapor derived with GPS, radiosondes, and microwave radiometer. J. Atmos. Oceanic Technol., 22, 201-210.

Vogelmann, A. M., V. Ramanathan, W. C. Conant, and W. E. Hunter, 1998: Observational constraints on non-Lorentzian continuum effects in the near-infrared solar spectrum using ARM ARESE data. J. Quant. Spectrosc. Radiat. Transfer, 60, 231-246.

Wang, J., H. L. Cole, D. J. Carlson, and A. Paukkunen, 2001: Performance of Vaisala RS80 radiosonde on measuring upper-tropospheric humidity after corrections. Preprints, 11th Symp. on Meteorological Observations and Instrumentation, Albuquerque, NM, Amer. Meteor. Soc., 94-97.

,,--- E. R. Miller, K. Beierle, A. Paukkunen, and T. K. Laine, 2002: Corrections of humidity measurement errors from the Vaisala RS80 radiosonde-Application to TOGA COARE data. J. Atmos. Oceanic Technol., 19, 981-1002.

Ware, R., C. Alber, C. Rocken, and F. Solheim, 1997: Sensing integrated water vapor along GPS ray paths. Geophys. Res. Lett., 24, 417-420.

Wolfe, D. E., and S. I. Gutman, 2000: Developing an operational, surface-based, GPS, water vapor observing system for NOAA: Network design and results. J. Atmos. Oceanic Technol., 17, 426-440. 